\title{
ATTRACTING FOREIGN DIRECT INVESTMENTS: THE CASE OF LATGALE REGION
}

\author{
Sandra Ežmale \\ Rezekne Academy of Technologies, Latvia
}

\begin{abstract}
Recent theoretical and empirical studies show that foreign direct investment (FDI) is crucial for sustainable development of countries and regions. The various discussions among the regional development institutions in Latvia on the importance of improving the environment for successful attraction of foreign investments have been initiated, as well as new strategic initiatives are in the process of development. The aim of the paper is to analyse the latest trends of inward FDI flows in Latvia and Latgale region in the context of global FDI trends. To attain the aim, the global FDI trends, the inward FDI flows in Latvia and Latgale region, as well strategic framework of Latgale region for attracting FDI were analysed.
\end{abstract}

Keywords: foreign direct investment, inward FDI, strategic planning.

\section{Introduction}

Recent theoretical and empirical studies show that foreign direct investment (FDI) is crucial for sustainable development of countries and regions. Over the last decade, it has grown rapidly as a key form of capital transfer across national borders. More than one third of the world's trade today are in the form of intra-firm transactions, which is the trade between the different parts of the same corporation across the borders. FDI and the operations of multinational enterprises have become essential to the world's economy in general. However, the effect of the global economic crisis and geopolitical situation continues to shape investment flows and to influence policy initiatives.

FDI brings new products and services into the host economy, generating demand for these products. First, the new products lead to creation of new markets and entrepreneurial opportunities (horizontal effects). Second, new firms may seek to exploit niche opportunities within sectors neglected by foreign-owned firms. FDI secures support for trade flows, boosts export competitiveness and stimulates import-competing production. Finally, the FDI can help new firms extend their activities by subcontracting or by developing collaborations for different activities (vertical effects). (Albulescu \& Tamasila, 2013) 
The world FDI market is highly competitive. All countries, regions, cities compete for FDI. Besides, this competition is quite similar in terms of a national legal investment framework and in addition, many countries have complemented and enhanced their regulatory frameworks with international investment agreements. Therefore, the challenge for countries is to develop and strengthen a reputation for being an excellent place for foreign investors.

The aim of the research is to analyse the latest trends of inward FDI flows in Latvia and Latgale region in the context of global FDI trends. Several tasks have been set within the framework of the research:

- $\quad$ to describe the global FDI trends in 2014;

- to analyse inward FDI flows in Latvia and Latgale region, as well strategic framework of Latgale region for attracting FDI.

The logic analysis and synthesis methods, monographic and analytical methods of research, descriptive statistical methods were applied to accomplish the tasks.

\section{Trends in global foreign direct investment}

The global economy is still developing in an uneven way and overall global growth in 2014 reached 3.3\% compared to 2013. Global economic development trends last year were determined by several global events - geopolitical instability in Ukraine and the Middle East, low economic growth in the euro area, as well as the sharp fall in oil prices in late 2014. Overall, global growth is slowly accelerating, but the growth rate is not as strong as expected. Economic growth of the EU in 2014 reached 1.3\%. Although still low, this growth rate is a step forward in comparison with previous years, when the EU GDP in 2012 dropped by $0.5 \%$ and in 2013 remained stable. (UNCTAD, 2015)

FDI inflows show the most rapid decrease in the last 10 years in developed countries. FDI inflows fell by 16 per cent to 1.23 trillion dollars in 2014, mostly because of the unstable global economy, policy uncertainty for investors and high geopolitical risks. Inward FDI flows to developing economies reached their highest level at 681 billion USD dollars with a 2 per cent rise. Among the highest 10 FDI recipients in the world, 5 are the developing economies and China became the world's largest recipient of FDI. Among the developing countries, the performance of Asia, Latin America and the Caribbean, and Africa was uneven in 2014. (AIM, 2015) Nine out of 20 largest investor countries were from developing or transition economies.

Finally, the economies in transition saw a dramatic fall in FDI inflows in 2014, minus 51 per cent, to 45 million euro. Russia accounted for the greatest 
share of the decline, in light of the conflict surrounding Ukraine and the sanctions imposed on Russia in response. (AIM, 2015)

Key global FDI tendencies: (1)Western Europe was the leading source region; (2) India, Vietnam, Japan and Malaysia were four of the fastest growing destination countries; (3) inward investment into the region consisting of Russia, the Commonwealth of Independent States, and Central, Eastern and Southeastern Europe declined by 24\%; (4) FDI into Europe by project numbers fell by nearly $17 \%$ in 2014, in contrast to near 7\% growth in FDI in North America; (5) FDI into Russia declined by $39 \%$ and the top five biggest investors in Russia were all Chinese Companies; (6) FDI into Ukraine was hit hard, with $80 \%$ declining capital investment and 64\% decline in FDI projects. (FDI, 2015)

Despite the economic downturn in the world and Europe, EY's attractiveness survey - Europe 2015(EY's, 2015) concludes that Europe in 2014 comparing with 2013 faced increase in FDI of $36 \%$. Share of Europe in total amount of the world increased from $17 \%$ in 2013 till $24 \%$ in 2014. (UNCTAD, 2015) The leading countries according to the FDI projects were the United Kingdom (887 projects, $11 \%$ increase) and Germany (763 projects, $9 \%$ increase). In 2014, countries in Central and Eastern Europe overtook their Western counterparts to secure the greatest number of FDI jobs. Eastern countries attracted much bigger projects than Western peers, but national trends vary. The Baltic States - Estonia, Latvia and Lithuania -have strong links to Scandinavia, and together attracted a total of 101 FDI projects in 2014.

Software projects continue to lead service-sector inflows, which are dominated by US investors (40\%). High costs in Western European capitals and a drive to set up regional European hubs helped CEE countries whose affordable, but able, talent pools attracted more than twice as many projects and jobs as in 2013 (57 projects and 11,825 jobs). (EY's, 2015)

According to the results of EY's attractiveness survey - Europe 2015 of those interviewed $85 \%$ believe that Europe will return to sustainable economic growth. Only slightly more than a half of them $(54 \%)$ believe sustainable growth will return in less than five years. $59 \%$ of investors believe that Europe will become more attractive in the next three years. Business leaders believe high value-added sectors, such as ICT, pharmaceuticals and clean tech will be the future vectors of investment and growth in Europe. The digital transformation is clearly driving massive economic and social change in Europe. ICT is attracting massive investments; software is already the number one sector for FDI projects in Europe. Investing in markets of the future: ICT (31\%) and pharma-biotech $(25 \%)$. Investors believe that these sectors will drive Europe's growth. Bureaucracy is seen as the biggest threat to Europe's attractiveness $(20 \%$ of investors), outweighing slow growth. 


\section{Foreign direct investment in Latvia}

After several years of strong economic growth, when the Latvian economy grew by 4- 5\% per annum between 2011 and 2013, in 2014 Latvian GDP growth rates slowed down, demonstrating $2.4 \%$ growth. Economic growth became slower due to various internal and external factors, among which the most important is the escalation of the geopolitical situation, introduction of trade sanctions and the Russian economic recession. Despite the economic slowdown, Latvian GDP growth last year was one of the highest among EU Member States and by 1.1 percentage points above the EU average growth rate. Analysis of GDP from the expenditure side shows that, overall, in 2014 there was an increase in all components, but growth was mainly ensured by domestic consumption. (LR FM, 2025)

The stock inflow of FDI increased and reached the highest level in 2014 (14,57 million dollars) after Latvia's membership of the European Union in 2004 (see Table 1). Unfortunately, in 2014 investment activity remained weak Latvia received FDI in amount of 474 million dollars, which is less that the amount received from 2011. It is also three times less than the amount received in 2008 (1262 million dollars). However, in mid - 2014, a number of international rating agencies - Standard \& Poor's, Moody's Investors Service and Fitch Ratings - once again raised Latvia's national credit rating and for the first time since the crisis it reached the above average risk level A. In the medium term it is a positive signal to foreign investors. (LR FM, 2025)

Table 1 Dynamics of foreign direct investments in Latvia, 2010 - 2014 (million dollars) (UNCTAD, 2015)

\begin{tabular}{|l|c|c|c|c|c|}
\hline \multicolumn{1}{|c|}{$\begin{array}{c}\text { Foreign Direct } \\
\text { Investment }\end{array}$} & $\mathbf{2 0 1 0}$ & $\mathbf{2 0 1 1}$ & $\mathbf{2 0 1 2}$ & $\mathbf{2 0 1 3}$ & $\mathbf{2 0 1 4}$ \\
\hline Inflows & 380 & 1466 & 1109 & 903 & 474 \\
\hline Outflows & 19 & 62 & 192 & 411 & 137 \\
\hline $\begin{array}{l}\text { Value of announced } \\
\text { greenfield FDI projects }\end{array}$ & 702 & 606 & 1002 & 729 & 262 \\
\hline
\end{tabular}

Historically, most of Latvia's FDI inflow has come from neighbouring countries in the Baltic Sea region and other EU member states. According to the statistical data of the Bank of Latvia, the largest amounts of investment in 2014 were from the European Union countries - 4672 million euro or $39 \%$ of the total FDI stock in Latvia's economy, including from Sweden - 2511 million euro or $21 \%$ of the total FDI stock in Latvia's economy.

Overall, however, Latvia's FDI inflows cover a range of economic sectors. According to the statistical data of the Bank of Latvia, FDI division by sectors 
displays that greatest FDI was attracted by financial intermediation - FDI in real estate operations was $13.10 \%$, in manufacturing $-12.05 \%$ and in wholesale and retail trade $-10.25 \%$ of the total FDI stock.

However, the growth of FDI by sectors is not homogeneous. FDI in the manufacturing sector grew by $21.2 \%$, in transport and storage sector rose by $12.2 \%$, while FDI in the wholesale and retail trade sector grew by $29.7 \%$. At the same time, the slowdown in investment was registered in electricity, gas and heating sector by 19.4 and in the agricultural sector by $18.4 \%$ compared to 2013 .

According to the statistical data of territorial development planning information system (TAPIS) on the regional development indicators of Latvia, the most successful regions in attracting foreign direct investments in the last five years were Riga region (1.756 million euro in 2014) and Kurzeme region (0.107 million euro in 2014) (see table 2).

Unfortunately, in 2014 investment activity in Latvia's regions was weak. Only two regions - Zemgale and Kurzeme regions increased the total amount of FDI.

Table 2 Foreign direct investments by regions in Latvia (million euro) (TAPIS)

\begin{tabular}{|l|r|r|r|r|r|}
\hline \multicolumn{1}{|c|}{ Planning regions } & \multicolumn{1}{c|}{$\mathbf{2 0 1 0}$} & \multicolumn{1}{c|}{$\mathbf{2 0 1 1}$} & \multicolumn{1}{c|}{$\mathbf{2 0 1 2}$} & \multicolumn{1}{c|}{$\mathbf{2 0 1 3}$} & \multicolumn{1}{c|}{$\mathbf{2 0 1 4}$} \\
\hline Riga region & 0.395 & 1.347 & 0.101 & 7.965 & 1.756 \\
\hline Vidzeme region & 0.016 & 0.083 & 0.033 & 0.034 & 0.016 \\
\hline Zemgale region & 0.002 & 0.018 & 0.002 & 0.014 & 0.058 \\
\hline Latgale region & 0.01 & 0.016 & 0.001 & 0.041 & 0.032 \\
\hline Kurzeme region & 0.1 & 0.146 & 0.096 & 0.032 & 0.107 \\
\hline
\end{tabular}

The greatest amount of FDI in 2014 was attracted by Riga region $-89 \%$ of the total amount of FDI in Latvian regions.

\section{Foreign direct investment in Latgale region}

The cities are the most attractive places for FDI attraction in Latgale region. City of Daugavpils had the largest amount of inflow FDI (33, 37 million euro in 2014). The second largest amount of FDI belonged to Rezekne city (5,2 million EUR) followed by Krāslava county (4,1 million EUR). 9 out of 11 most attractive places for FDI inflows in Latgale region were cities of national importance (Rezekne and Daugavpils), as well as regional development centres like Krāslava, Līvāni, Balvi, Ludza, Preiḷi. Rural areas had very low FDI inflows. In Ilūkste county the major part of FDI was composed of a single investment project in the company "LatRosTrans", placing it in a top position (see table 3). 
Table 3 Foreign direct investment in municipalities of Latgale Region 1994- 2014 ( LPR INPP, 2014)

\begin{tabular}{|l|c|c|c|}
\hline \multicolumn{1}{|c|}{ County/City } & $\begin{array}{c}\text { FDI 1994-2004, } \\
\text { EUR }\end{array}$ & $\begin{array}{c}\text { FDI 2004-2014, } \\
\text { EUR }\end{array}$ & FDI, total, EUR \\
\hline Daugavpils City & 46506964.53 & -13138358.97 & 33368605.56 \\
\hline Ilūkste & 52011656.17 & -20170446.98 & 31841209.19 \\
\hline Rēzekne City & 1546024.21 & 3624120.13 & 5170144.34 \\
\hline Krāslava & 360141.75 & 3762005.14 & 4122146.89 \\
\hline Līvāni & 2457322.38 & 278245.36 & 2735567.74 \\
\hline Rēzekne County & 299874.50 & 2149258.95 & 2449133.45 \\
\hline Balvi & 29773.59 & 1520671.48 & 1550445.07 \\
\hline Ludza & 11286.22 & 1126236.32 & 1137522.54 \\
\hline Daugavpils County & 310548.89 & 519307.07 & 829855.96 \\
\hline Dagda & 3414.89 & 404091.84 & 407506.73 \\
\hline Preilịi & 275012.66 & -6858.24 & 268154.42 \\
\hline Vị̄āni & 159589.30 & 31977.81 & 191567.11 \\
\hline Baltinava & 0.00 & 32726.05 & 32726.05 \\
\hline Rugāji & 0.00 & 19877.56 & 19877.56 \\
\hline Vị̦aka & 0.00 & 10045.47 & 10045.47 \\
\hline Kārsava & 428995.85 & -419747.18 & 9248.67 \\
\hline Cibla & 4560.30 & 1131.19 & 5691.49 \\
\hline Vārkava & 5051.19 & 640.30 & 5691.49 \\
\hline Riebiṇi & 0.00 & 4516.32 & 4516.32 \\
\hline Zilupe & 7825.80 & -3365.93 & 4459.87 \\
\hline Aglona & 0.00 & 1421.45 & 1421.45 \\
\hline
\end{tabular}

The biggest amount of FDI in Latgale region was invested in the enterprises in Daugavpils and Rēzekne (see table 4).

This trend emphasizes the weight of urban areas in investment attraction.The sectorial composition of FDI in Latgale region (1994- 2004) was the following: land transport and transport through pipelines - 40. $57 \%$, manufacture of other transport equipment $-13.27 \%$ manufacture of chemicals and chemical products $-6.88 \%$, wholesale trade $-5.21 \%$, manufacture of wood and product of wood and cork $-5.02 \%$, civil engineering $-3.94 \%$, real estate activities $-3.26 \%$, manufacture of machinery and equipment $-3.08 \%$ e.g. (LPR INPP, 2015) 
Proceedings of the International Scientific Conference. Volume IV, May $27^{\text {th }}-28^{\text {th }}$, 2016. 256-266

Table 4 FDI in Latgale region by investors (2014) (Lursoft, 2015)

\begin{tabular}{|c|c|c|c|c|}
\hline No & Investor & Location/ Enterprise & Industry & FDI (euro) \\
\hline 1 & $\begin{array}{c}\text { AK } \\
\text { „TRANSNEFTE } \\
\text { PRODUKT", } \\
\text { OAO } \\
\text { (Russian } \\
\text { Federation) } \\
\end{array}$ & $\begin{array}{l}\text { Ilūkste county, } \\
\text { LatRosTrans, SIA }\end{array}$ & Pipeline transport & 9348823 \\
\hline \multirow[t]{2}{*}{2} & \multirow[t]{2}{*}{$\begin{array}{l}\text { Skinest Rail AS } \\
\text { (Estonia) }\end{array}$} & $\begin{array}{l}\text { Daugavpils, } \\
\text { Daugavpils Lokomotīvju } \\
\text { Remonta Rūpnīca, A/S }\end{array}$ & $\begin{array}{l}\text { Manufacture of } \\
\text { other transport } \\
\text { equiptment }\end{array}$ & \multirow[t]{2}{*}{5664242} \\
\hline & & SIA „DLRR Wood” & $\begin{array}{l}\text { Manufacture of } \\
\text { wood and of } \\
\text { products of wood } \\
\text { and cork }\end{array}$ & \\
\hline 3 & $\begin{array}{l}\text { Nexis Fibers a.s. } \\
\text { (Slovak Republic) }\end{array}$ & $\begin{array}{l}\text { Daugavpils, } \\
\text { Nexis Fibers, SIA }\end{array}$ & $\begin{array}{l}\text { Manufacture of } \\
\text { chemicals and } \\
\text { chemical products }\end{array}$ & 5340524 \\
\hline 4 & $\begin{array}{l}\text { Panevežio Keliai, } \\
\text { Akcine bendrove } \\
\text { (Lithuania) }\end{array}$ & $\begin{array}{l}\text { Daugavpils, } \\
\text { Latgales Cel̦daris, SIA }\end{array}$ & Civil engineering & 3086920 \\
\hline 5 & $\begin{array}{l}\text { Spacecom AS } \\
\text { (Estonia) }\end{array}$ & $\begin{array}{l}\text { Daugavpils, } \\
\text { Daugavpils Lokomotīvju } \\
\text { Remonta Rūpnīca, A/S }\end{array}$ & $\begin{array}{l}\text { Manufacture of } \\
\text { other transport } \\
\text { equipment }\end{array}$ & 2982339 \\
\hline 6 & $\begin{array}{l}\text { DAN LET } \\
\text { NATIONAL } 21 \\
\text { ApS (Denmark) }\end{array}$ & $\begin{array}{l}\text { Krālsava county, } \\
\text { DEN LAT International } \\
\text { 21, SIA }\end{array}$ & $\begin{array}{l}\text { Real estate } \\
\text { activities }\end{array}$ & 3301062 \\
\hline 7 & $\begin{array}{l}\text { OU Lokomotiiv } \\
\text { Investeeringuud } \\
\text { (Estonia) }\end{array}$ & $\begin{array}{l}\text { Daugavpils, Daugavpils } \\
\text { Lokomotīvju Remonta } \\
\text { Rūpnīca, A/S }\end{array}$ & $\begin{array}{l}\text { Manufacture of } \\
\text { other transport } \\
\text { equipment }\end{array}$ & 1813906 \\
\hline 8 & $\begin{array}{l}\text { CLEAR } \\
\text { ENERGY } \\
\text { HOLDINGS S.A. } \\
\text { (Luxembourg) }\end{array}$ & $\begin{array}{l}\text { Rēzekne, } \\
\text { NewFuels, RSEZ SIA }\end{array}$ & $\begin{array}{l}\text { Manufacture of } \\
\text { wood and of } \\
\text { products of wood } \\
\text { and cork }\end{array}$ & 1779841 \\
\hline 9 & $\begin{array}{l}\text { CLEAR } \\
\text { ENERGY } \\
\text { HOLDINGS S.A. } \\
\text { (Luxembourg) }\end{array}$ & $\begin{array}{l}\text { Rēzekne, } \\
\text { Atmos clear CHP RSEZ } \\
\text { SIA }\end{array}$ & $\begin{array}{l}\text { Manufacture of } \\
\text { wood and of } \\
\text { products of wood } \\
\text { and cork }\end{array}$ & 1778762 \\
\hline 10 & $\begin{array}{l}\text { C.I.G Capital } \\
\text { Invest Gaz Ltd } \\
\text { (Cyprus) }\end{array}$ & $\begin{array}{l}\text { Daugavpils, INTERGAZ, } \\
\text { SIA }\end{array}$ & Wholesale trade & 1406764 \\
\hline 11 & $\begin{array}{l}\text { Martin Ziegler } \\
\text { GmbH and Co. } \\
\text { KG (Germany) }\end{array}$ & $\begin{array}{l}\text { Daugavpils, ZIEGLERA } \\
\text { MA S̄INNBŪVE, SIA }\end{array}$ & $\begin{array}{l}\text { Manufacture of } \\
\text { machinery and } \\
\text { equipment n.e.c. }\end{array}$ & $\begin{array}{c}1196 \\
902,00\end{array}$ \\
\hline
\end{tabular}


The biggest amount of FDI inflows were invested and the greatest number of FDI projects were implemented in Latgale region by investors from Russia $43 \%$ from the total amount of FDI and 307 FDI projects in 2014. Investors from Estonia, Germany, Switzerland and Lithuania composed more than $34 \%$ of FDI in Latgale region with 217 projects (see table 5).

Table 5 FDI projects in Latgale region by countries (2014)

\begin{tabular}{|c|l|c|c|}
\hline No & \multicolumn{1}{|c|}{ Country } & FDI (euro) & Number of projects \\
\hline 1 & Russian Federation & 38548210,9 & 307 \\
\hline 2 & Estonia & 8959256 & 44 \\
\hline 3 & Germany & 4425090,72 & 46 \\
\hline 4 & Confederation of Switzerland & 3841688 & 9 \\
\hline 5 & Lithuania & 2855695,106 & 118 \\
\hline
\end{tabular}

Source, Lursoft, 2014

However, the largest amount of FDI per investor were from the European countries (Luxembourg, Switzerland, Estonia, Cyprus and Denmark). Investors from these countries invest in larger projects, while investors from CIS countries and Lithuania on average invest in many small-scale projects.

\section{Strategic framework of Latgale region for attracting FDI}

The most important issue is the locational FDI determinant. Among these, the most important are economic factors, in particular the size and growth of the market, the appropriate quality of the infrastructure, including transport and logistics infrastructure, and the diversity and quality of labour force, as well as science and technology resources and research and innovation capacity. The entrepreneurs' satisfaction with business environment in Latgale region is most closely correlated with the access to the local market, competitive real estate prices and provision and quality of technical infrastructure (Ezmale \& Litavniece, 2011).The situation reflecting that these basic economic determinants have been developed in many countries explains high competition between countries and regions to attract FDI. Policy creators and planners at different administrative levels adopt decisions on the distribution of economic activities in a space and the political and strategic framework influence on decisions for the investment allocation.

Strategy for Investment Attraction to Urban Areas in LV-LT Cross-Border Region (Investment Attraction Strategy) describes the main strategic priorities for attracting FDI to Latgale-Ignalina region. The Investment Attraction Strategy outlined the lack of investment attraction activities, lack of skilled 
labour force, macroeconomic barriers and location of a region as the weaknesses of the Latgale- Ignalina region. At the same time Latvia Investment and Development Agency and Rezekne Special Economic Zone Authority delineated that Latvia and Latgale region have advantageous geographic location between the EU and CIS countries and direct access to more than 500 million consumers of the European Union. Important is the fact that Daugavpils University and Rezekne Academy of Technologies in Latgale region have high quality study programmes with modern study and research infrastructure to improve knowledge and skills of labour force in relation to the engineering sciences, like ICT, mechatronics, electronic commerce, environmental engineering e.g. (LPR INPP, 2014)

The Investment Attraction Strategy (LPR INPP, 2014) defined that the goal is to become one of the leading regions in Latvia in foreign direct investment attraction to manufacturing industries by year 2021. To achieve the objective, four priorities have been set:

1) priority "Developing Industrial Parks for Fast and Low Cost Manufacturing Setup";

2) priority "Building Competences to Support Industry Clusters", includes measures aimed at improving accessibility of skilled labour force in Latgale-Ignalina region by creating cluster-supporting competence network;

3) priority "Running Pro-Active Investment Marketing by Strengthening Regional Institutions" is aimed at tackling the challenge of insufficient mass of investors by creating departments at regional institutions working directly with investment marketing and investor attraction;

4) priority "Fast Logistical Connections" includes actions for developing transport infrastructure and setting up logistical parks by the EU external border.

The sectorial distribution of FDI can be a significant factor that determines the influence of FDI on a capital formation process. When the sectorial distribution of FDI is substantially different from the distribution of the existing capital stock or production, the contribution of FDI to capital formation will be more positive than when the distribution of FDI follows roughly the existing sectorial distribution of the capital stock. In other words, the relationship between FDI and domestic investment is likely to be complementary when investment is in an undeveloped sector of the economy (Titarenko, 2006). Therefore, the primary aim is to find the new incentives for FDI inflow in the less developed industrial sectors of Latgale region where the foreign investors will contribute to new technologies, introduce new products and stimulate higher activity of domestic firms ensuring the investment effect. 
For Latgale region there is a defined specialisation in manufacturing of machinery, transport equipment, textile and wearing apparel, food production, manufacture of wood products. These sectors are traditional and strong in Latgale region. One of the most promising sectors for FDI in previous years was the communications' sector. These sectors globally represent an increase of $82.2 \%$ on the 2012 spending and the highest capital investment figure for the communications' sector since such data in 2003. The high value-added sectors, such as ICT, pharmaceuticals and clean tech will be the future vectors of investment and growth in Europe. Therefore, it will be important to set Latgale region additional specialisation for attracting FDI in the sectors which are less developed at the moment, but at the same time most perspective, like ICT, logistics and transportation, clean tech.

\section{Conclusion}

Recent theoretical and empirical studies show that foreign direct investment is crucial for sustainable development of countries and regions. FDI provides capital inflows that have positive impact on finance current account deficit and facilitates compensation of the insufficient capital formation of the local enterprises. Furthermore, FDI stimulate the transfer of technology that cannot be achieved only through trade of goods and services, as well as financial investments. FDI can also encourage competitiveness of domestic trough improvement of knowledge and managerial skills. It means that FDI can serve as an important complement to domestic investment in building productive capacity to advance growth and development, but to be successful in attracting FDI, the right factors have to be improved.

FDI can serve as an important complement to domestic investment in building productive capacity to advance growth and development. FDI is a tool for that purpose. But to be successful in attracting such investment, the proper FDI determinants need to be in place.

Most important preconditions for FDI are the following:

- reduced cost of compliance and production;

- competitive locational advantages (reliable infrastructure, utilities, transportation networks and logistics e.g.)

- flexibility in terms of resource allocation (labour, capital, equipment e.g);

- productive, skilled labour force.

It could be concluded that through elaboration of strategic documents, Latgale region should pay greater attention to the above mentioned aspects. It would convince potential investors that the regional and local authorities take all 
necessary measures to improve the business climate and increase competitiveness in the territory. By providing measures to increase the investment attractiveness in strategic documents, it would create favorable conditions for FDI attractiveness improvement in the future. It is important also to find new incentives for FDI inflow in the less developed industrial sectors of Latgale region where the foreign investors can contribute to new technologies, introduce new products and stimulate higher activity of domestic firms ensuring the investment effect.

\section{References}

AIM (2015). Investment Reort 2015: Trends and Policy Challenges. Downloaded from http://ccsi.columbia.edu/files/2015/03/AIM-Investment-Report-2015-website-.pdf

Albulescu, C.T., \& Tamasila, M. (2014). The impact of FDI on entrepreneurship in the European Countries. Procedia - Social and Behavioral Sciences 124, 219 - 228.

EY's (2015). Attractiveness survey. Europe 2015. Downloaded from http://www.eyeim.com/ pdf/EY\%202015\%20European\%20attractiveness\%20survey.pdf

Ezmale, S., \& Litavniece, L. (2011) Spatial Planning as a Tool for Improving Attractiveness of the Places: Case of Latgale Region. European Integration Studies. Research and Topicalities. No.5. Kaunas Univeristy of Technologies, 2011., $20-25$.

FDI (2025).The fDi report 2025. Downloaded from http://report.fdiintelligence.com/

Kearney, A.T. (2015).Foreign Direct Investment Confidence Index. Downloaded from https://www.atkearney.com/research-studies/foreign-direct-investment-confidenceindex/2015/publication

LPR INPP (2014).Investment attraction strategy, 2014.

LR FM (2015). Latvia's Stability Programme for 2015-2018. . Downloaded from http://ec.europa.eu/europe2020/pdf/csr2015/sp2015_latvia_en.pdf

Titatrenko, D. (2006). The influence of foreign drirect investment on domestic investment processes in Latvia. Transport and Telecommunication, Vol.7, No 1, 2006, 8 p.

UNCTAD (2015). World Investment Report 2015: Reforming International Investment Governance. Downloaded from

http://unctad.org/en/PublicationsLibrary/wir2015_en.pdf 